\title{
ULTRASTRUCTURAL CHANGES IN ORIZA SATIVA, Echinochloa colonum AND Echinochloa crus-galli TREATED WITH FENOXAPROP-P-ETHYL AND PENOXSULAM HERBICIDES.

\author{
El-Nady, M. F. ${ }^{2}$; A. A. Zein ${ }^{1}$; M. A. Ashry ${ }^{1}$ and Sh. Abdel-dayem ${ }^{1}$ \\ ${ }^{1}$ Dept. of Pesticides and ${ }^{2}$ Dept. of Agric. Botany, Fac. of Agric.,
} Kafrelsheikh Univ., Egypt
}

\begin{abstract}
Cytological changes in rice Oriza sativa (L.) cv. Sakha 104, and two different rice weeds i.e. Echinochloa colonum (L.) and Echinochoa crus-galli (L.) after foliar application with fenoxaprop-P-ethyl at rate of $26.25 \mathrm{~g}$ a.i /fed. and penoxsulam at rate of $10 \mathrm{~g}$ a.i/fed. were investigated. Mesophyll cell plasmolysis and unevenly thickened cell walls were showed in $O$. sativa after foliar application with fenoxaprop-P-ethyl. Mitochondria multi- fission and increasing in mitochondria number per cell were found in rice and E. crusgalli mesophyll cells. Thylakoid membrane reduction and plastoglubule were noticed in chloroplast of mesophyll cells in $E$. colonum were recorded. Furthermore, re-growth of E. crus-galli and E. colonum occurred after foliar application with fenoxaprop-P-ethyl. These findings will improve our understanding for the tested herbicides mode of action in wanted and unwanted plants at ultrastructural levels.

Keywords: Plasmolysis, programmed cell death, thylakoid, mitochondria multi-fission, re-growth, cytological changes, irregular nucleus

\section{INTRODUCTION}

Fenoxaprop-P-ethyl is a member of the aryloxyphenoxy propionate (AOPP) herbicide family. These herbicides inhibit acetyl Co-enzyme A carboxylase (ACCase) and are used to control annual grass weeds such as rice weeds (Echinochloa colonum (L.) and Echinochoa crus-galli (L.). Fenoxaprop-P-ethyl is used as post emergence herbicide to control various annual grass weeds in rice and other crops (Gronwald, 1991 and WSSA, 1994). and was introduced to California in the early 1990s to control Echinochloa spp. and Leptochloa fascicularis (Lam.). On the other hand Penoxsulam is a systemic herbicide that is absorbed mainly by leaves and secondarily by roots (Larelle et al., 2003). This herbicide is a member of the triazolopyrimidine sulfonamide (TPS) chemical family, and its mechanism of action is the inhibition of the acetolactate enzyme (ALS), which impedes the biosynthesis of the branched-chain amino acids valine, leucine, and isoleucine. These herbicides, known as ALS-inhibitors (acetohydroxy acid synthase inhibition), have enjoyed increasing popularity among farmers worldwide and have been extensively used due to their high efficacy at low rates, low impact on non-target organisms (including mammals), low residual
\end{abstract}


activity and persistence and high selectivity in several crops (Moss \& Cussans, 1991; Heap, 1997).

Echinochloa colonum (L.) is a severe competitor of rice and is one of the world's worst weeds; It is an alternate host of the fungus Pyricularia oryzae, which causes rice blast, the root-knot nematode Meloidogyne incognita,Chitwood, the yellow stem borer (Scirpophaga incertulas) and of the viruses that produce hoja blanca disease and tungro disease of rice (Naples and Kessler 2005). Yield losses caused by Echinochloa spp infestations in rice can be very severe and variable as far as the cultivar and the duration of competition are concerned. An infestation of $E$. colonum (L.) Link resulting from the sowing of about 40 viable seeds caused yield losses ranged from 27 to $62 \%$ (Fischer et al., 1997). These findings reflect the great risk of this weed on rice production in Egypt and worldwide.

Echinochloa crus-galli (L.) Beauv is a type of wild grass originating from tropical Asia that was formerly classified as a type of panicum grass. Considered as one of the world's worst weeds, it reduces crop yields and causes forage crops to fail by removing up to $80 \%$ of the available soil nitrogen. Individual plants can produce up to 40,000 seeds per year. More than $35 \%$ of grain yield in seeded rice was reduced by infestation with $E$. crus-galli (Naples and Kessler, 2005).

Rice (Oryza sativa) is one of the most important cereal crops in the world, providing staple food for nearly one half of the global population. In many developing countries, rice is the main source of food security and is intimately associated with local lifestyles and culture. With rapid increase of global population, much greater rice production is demanded, (Bao- Rang, 2004). Rice production will have to increase by $65 \%$ by 2020 to cope with the estimated population growth in rice-consuming countries (IRRI, 1989).

Weeds are unanimously considered one of the most costly and limiting factors in crop production. Losses caused by weeds primarily derive from direct competition with crop plants for water, nutrients, light and space, which results in significant yield reductions (Rosskopf et al., 1999). Besides these direct implications, weeds can also serve as alternate hosts to insect pests and pathogens, often resulting in additional operating costs and increased risk of diseases (Wisler and Norris, 2005).

Without weed control, yield losses have been estimated to range from $16 \%$ to $86 \%$ or even $100 \%$ (Zoschke 1990; Baltazar and De Datta 1992; Kropff 1993 and Hassan, et .al 2002). Intensive cropping systems are based on a strong reliance on herbicides, which belong to the most reliable and cost-effective tools for weed control (Powles \& Shaner, 2001). Herbicides are compounds used to kill unwanted plants, mainly by inhibiting the activity of specific target enzymes associated with the catalysis of biosynthetic processes that are essential for plant growth (Powles and Yu, 2010). These topics have been investigated, but there are not any ultrastructural studies in the literature that have used the tested herbicides to point out the cytological changes in unwanted plants (rice weeds) and wanted plant (rice plant), which may improve our understanding of the herbicides mode of action. Therefore, the main objective of this study was to investigate the cytological 
changes in both target and non-target plants as a result to fenoxaprop-P-ethyl and penoxsulam foliar application.

\section{MATERILAS AND METHODS}

\section{Plant material and procedure:}

Pot experiments were carried out in the greenhouse of Agricultural Botany Dept., Faculty of Agriculture, Kafrelsheikh University, Egypt, during 2011 rice growing season. The experiments were conducted in order to study the cytological effects of fenoxaprop-P-ethyl with the trade name of" Whip super $7.5 \%$ E.W" at rate of $26.25 \mathrm{gai} / \mathrm{fed}$, and penoxsulam with the trade name "Rainbow, 2.5\% O.D." at rate of $10 \mathrm{~g}$ a.i/fed.on rice plants cv. Sakha 104 and two different rice-weeds i.e E. colonum and E. crus-galli.

The soil used in this experiment was fertilized with nitrogen at rate of 360 $\mathrm{kg} / \mathrm{h}$ of urea fertilizer (contains $46 \%$ nitrogen). Super phosphate fertilizer (phosphorus 15\%) was added at rate of $240 \mathrm{~kg} / \mathrm{ha}$ before planting. Potassium was not added because the Egyptian soil is rich in this element. Germinated seeds of rice plants and the two different rice weeds were planted in $30 \times 30$ $\mathrm{cm}$ plastic pots filled with soil. Emerged seedlings were thinned to four uniform and equally distant-spaced plants per pot. These experiments were conducted at average daily temperatures ranging from 22 to $31^{\circ} \mathrm{C}$ and at a 16-h day length. Pots were immersed with water up to $4 \mathrm{~cm}$ above the soil surface. The tested herbicides, fenoxaprop-P-ethyl and penoxsulam were applied as a single application using a hand sprayer at the 4-leaf to 1-tiller stage of growth of the tested weeds. After forty-eight hours from treatment, the plants were irrigated and water was raised up to $4 \mathrm{~cm}$ above the soil surface (Osuna et al. 2002). Experiments were done in a completely randomized design with six replications.

\section{Electron microscopic test}

The leaf specimens ( 3 specimens/treatment) were taken from the second leaf from the plant tip. Specimens were taken on the $10^{\text {th }}$ day of treatment. Specimens were fixed in $0.5 \%$ buffered glutaraldehyde in $0.1 \mathrm{M}$ PBS, $\mathrm{pH} 7.4$ at $40 \mathrm{C}$ for $2 \mathrm{~h}$. Specimens were washed three times with PBS (10 min. each) and post fixation in $1 \%$ Osmic acid for (30min). Washing three times with PBS (10 min. each), then dehydrated with ascending series of ethyl alcohol (30,50, 70, 90\% and absolute alcohol) each concentration for 30 min. infiltrated with acetone for 1 hour. In transmutation electron microscope (TEM), after dehydration samples were embedded in Araldite 502 resin (Spurr, 1969). The plastic molds were cut in the LEICA Ultracut UCT ultra-microtome, stained with $1 \%$ toleudine blue. After examination of semithin sections ultra-thin sections were cut, stained with uranyl acetate. then counter stained with lead citrate (Venable and Coggeshall, 1965), examined and photographed using JEOL-JEM-100 SX electron microscope, Japan, at Electron Microscope Unit, Tanta University. 


\section{RESULTS AND DISCUSSION}

Concerning cytological responses to fenoxaprop-P-ethyl at rate of $26.25 \mathrm{gai} / \mathrm{fed}$. and penoxsulam at rate of $10 \mathrm{~g}$ a.i/fed treatments data in Fig. 1 indicated that plasmolysed mesophyll cells, vacuolar vesicles, unevenly thickened walls (see arrows) and vacuolar inclusions were found in mesophyll cells of rice leaves after foliar application of this herbicide.
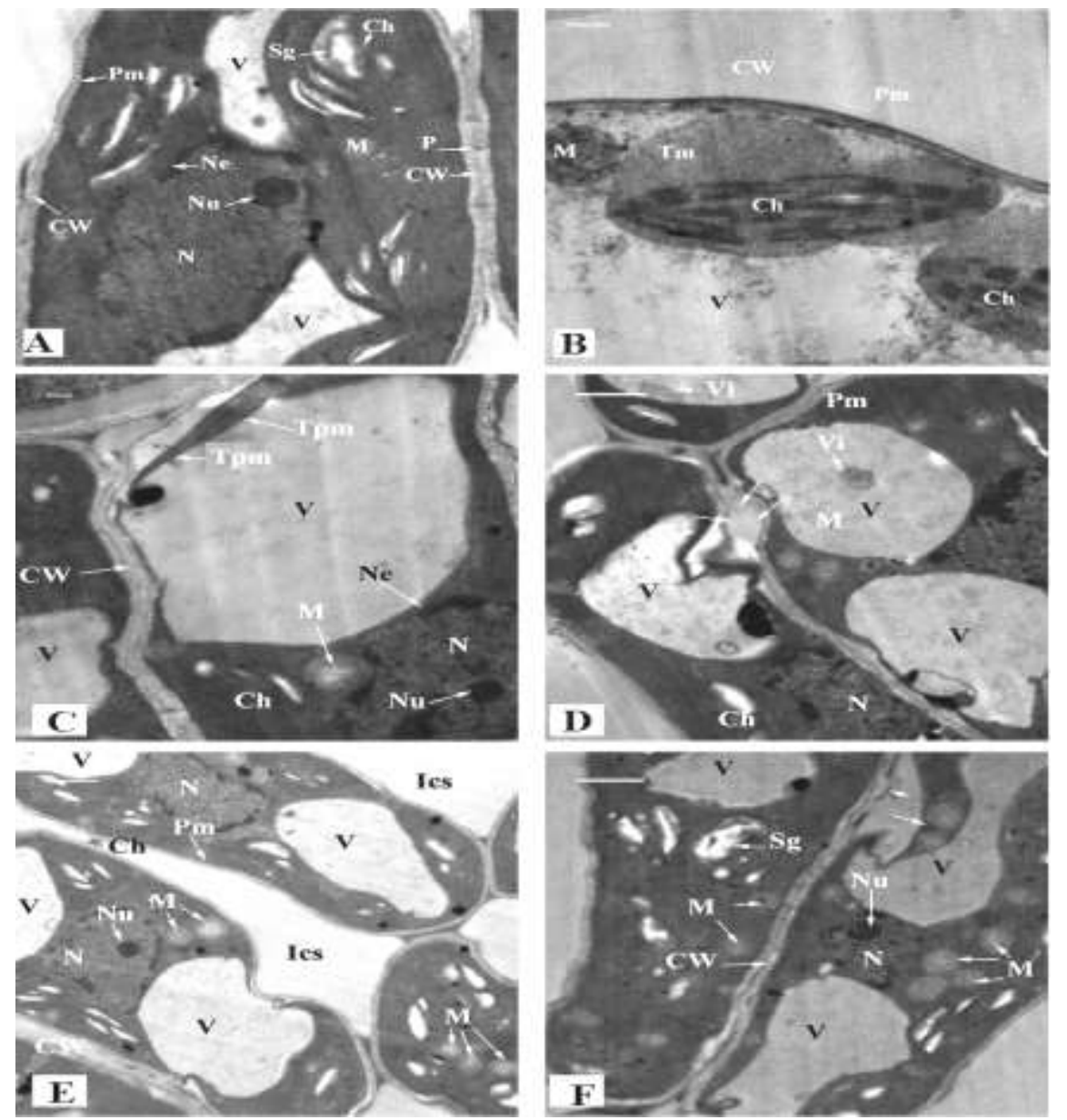

Fig. (1) Transmission electron micrograph of mesophyll cells of rice leaves showing cytological differences as affected by fenoxaprop-P-ethyl at rate of $26.25 \mathrm{~g}$ a.i /fed.and penoxsulam at rate of $10 \mathrm{~g}$ a.i/fed.: $A$ and $B$ : rice (control), $C$ and $D$ : rice with fenoxaprop-P-ethyl at rate of $25.26 \mathrm{~g}$ a.i /fed., $\mathrm{E}$ and $\mathrm{F}$ : rice with penoxsulam at rate of $10 \mathrm{~g}$ a.i/fed $\mathrm{CW}$ : cell wall, $\mathrm{Ch}$ : chloroplast, $\mathbf{M}$ : mitochondria, $\mathbf{N}$ : nucleus, Nu: nucleolus, $\mathrm{V}$ : vacuole, Pm: plasma membrane, Sg: Starch grain, Tpm: Tonoplasm membrane, Ics: inter cellular spaces (Bars: A-C; $500 \mathrm{~nm}, \mathrm{D}-\mathrm{F}=2 \mu \mathrm{m}$ ) 
Cell plasmolysis is a kind of adverse effect (cytotoxic features) of fenoxaprop-P-ethyl treatment. Concerning rice plants treated with penoxsulam at rate of $10 \mathrm{~g}$ a.i/fed, plasmolysis, multi-fission and high number of mitochondria per cell was detected in mesophyll cells of rice leaves as compared with untreated plants. Increasing in mitochondria numbers per cell is related to the higher rate of mitochondria fission, which led to increase in aerobic metabolic functions and reducing in dry weight accumulation. Abdeldaym, (2012) indicated that, relative water content and membrane integrity percentages were decreased in rice plants and in the tested rice weeds after foliar application with the same herbicide. These changes after herbicide foliar application are identified as cytological changes. Generally, reduction in relative water content and increase in membrane integrity led to cell plasmolysis.

Concerning the effect of fenoxaprop-P-ethyl at rate of $26.25 \mathrm{gai} / \mathrm{fed}$ and penoxsulam at rate of $10 \mathrm{~g}$ a.i/fed on E. crus-galli, data in Fig. 2 indicated that, fragmented vacuoles and vacuolar inclusions were found as response to fenoxaprop-P-ethyl treatment. Penoxsulam is a member of the triazolopyrimidine sulfonamide (TPS) chemical family, and also is a systemic herbicide which can be absorbed mainly by leaves and secondarily by roots (Larelle et al., 2003). and its mechanism of action is the inhibition of the acetolactate enzyme (ALS), which impedes the biosynthesis of the branchedchain amino acids valine, leucine, and isoleucine.

Fragmented vacuoles, irregular nucleus and increasing in the number of mitochondria were noticed as response of E. crus-galli to penoxsulam at rate of $10 \mathrm{~g}$ a.i/fed. Mitochondria and chloroplast fissions were found also. The number of mitochondria present in a cell depends upon the metabolic requirements of that cell. It has also been reported recently that leaf mitochondria may play a central role in counteracting environmental stresses by modulating cell redox homeostasis and by setting antioxidant capacity (Dutilleul et al., 2003). Plant mitochondria may also sense cellular stress early and regulate programmed cell death (PCD) (Jones, 2000; Rhoads et al., 2006). Furthermore, mitochondria may play a major role in interorganelle cross-talk under environmental/oxidative stresses by signalling with chloroplasts (Millar et al., 2001) and by inducing altered nuclear gene expression through mitochondria-to-nucleus signalling, which is referred to as mitochondrial retrograde regulation (Rhoads et al., 2006).

Data presented in Fig. 3 show the cytological differences as responce of E. colonum plants to fenoxaprop-P-ethyl at rate of $26.25 \mathrm{gai} / \mathrm{fed}$ and penoxsulam at rate of $10 \mathrm{~g}$ a.i/fed treatments. Mesophyll cells plasmolysis and multi-vesicles were found between the cell walls and plasma membranes as result of fenoxaprop-ethyl application. Thylakoid membranes were reduced as compared with the untreated plants. Fenoxaprop-ethyl is used as postemergence herbicide to control various annual grass weeds in rice and other crops (WSSA 1994). This herbicide is an aryloxyphenoxy propionate that inhibits acetyl coenzyme A carboxylase (ACCase; EC 6.4.1.2) (Gronwald 1991). Abdeldayem, (2012) found that chlorophyll content values were decreased in leaves of $E$. colonum treated with fenoxaprop-ethyl. 
Anderson (1996) and Valverde and Itoh (2001) reported that the application of fenoxaprop-P-ethyl as ACCase-inhibitor for controlling different weeds led to injury symptoms in the form of chlorosis as result of reduction in the chlorophyll content.

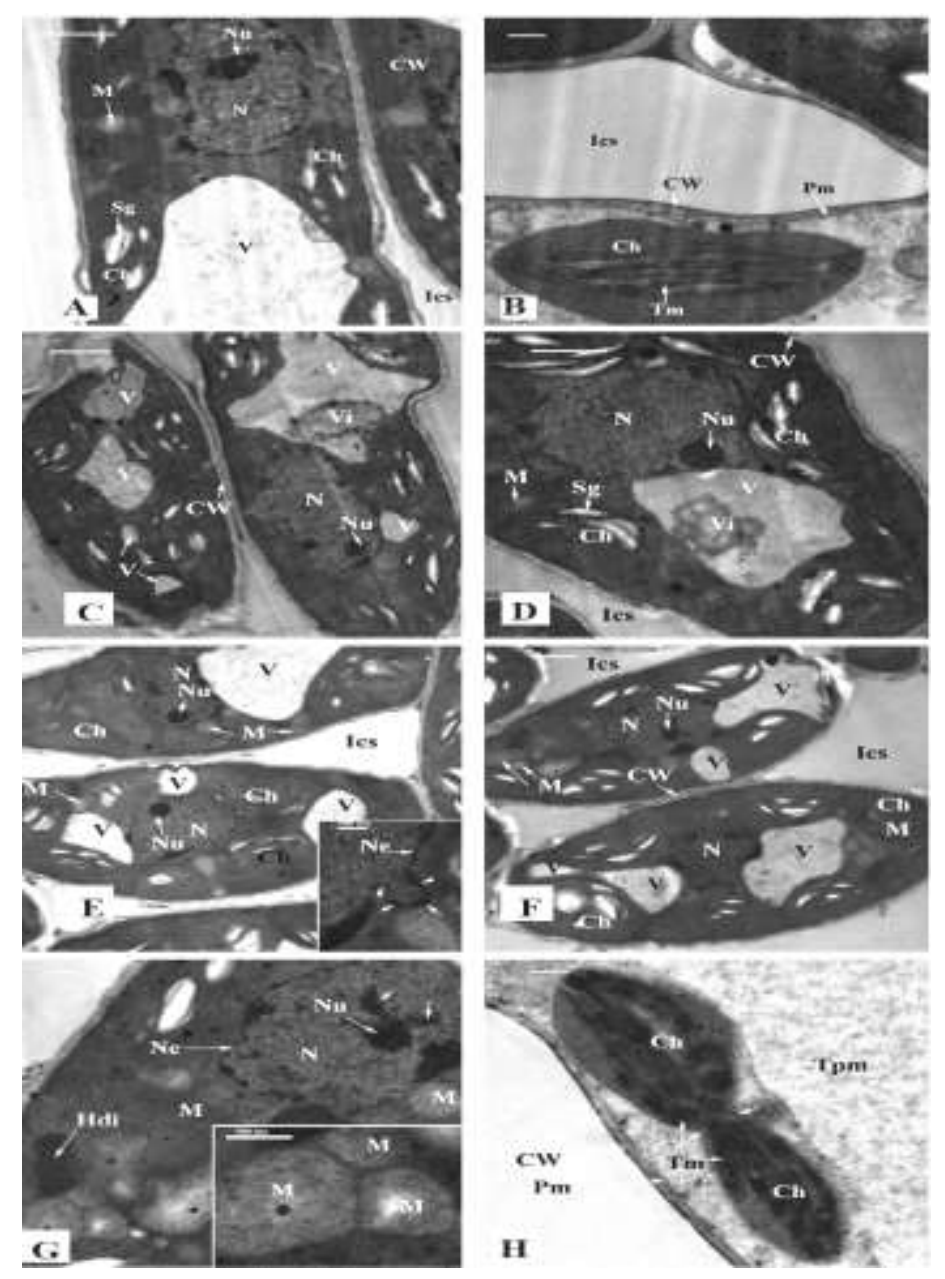

Fig. (2); Transmission electron micrograph of mesophyll cells of Echinochloa crus-galli. A- B: E. crus-galli (control), C and D E. crus-galli with fenoxaprop-P-ethyl at rate of $26.25 \mathrm{~g}$ a.i /fed., E - H: E. crus-gali with penoxsulam at rate of 10 g a.i/fed., CW: cell wall, Ch: chloroplast, M: mitochondria, $\mathrm{N}$ : nucleus, Nu: nucleolus, Nv: nuclear envelope, $\mathrm{V}$ : vacuole, Pm: plasma membrane, Tm: thylakoid membrane, Sg: Starch grain, Tpm: Tonoplasm membrane, Vi: vacuolar inclusions, Hdi: high density inclusions (Bars: $A-F=2 \mu \mathrm{m}$, G-H=500 nm) 
The reduction in chlorophyll content after foliar application of fenoxaprop-P-ethyl is likely to be due to its incorporation into the cell membrane function through physiological processes, such as depolarization of membrane potential (Wright, 1994) which is not clarified yet. Subsequently, this makes the translocation of fenoxaprop-p-ethyl become more difficult and thus, relatively large amount of the herbicide retained in the treated leaf tissue and reduce the chlorophyll content (Wright, 1994). Moreover, this reduction may be due to the enhanced activity of chlorophyll degrading chlorophyllase enzyme and/or disruption of the fine structure of chloroplast, and instability of chloroplast or pigment-protein complex, which leads to oxidation of chlorophyll and decreased its concentration. The possible mechanism of this reduction in thylakoid membrane due to the inhibition of fatty acids synthesis by fenoxapo-p-ethyl which is known as fatty acids synthesis inhibitor (Tal et al. 1993, Hosaka, et al. 1994 and Kuk et al., 1999) and subsequently disrupt the plasma membrane synthesis and functions.

On the other hand, cytological changes in E. colonum plants as responses to penoxsulam at rate of $10 \mathrm{~g}$ a.i/fed application, data in the same figure clarified that, intensive vacuolar inclusions and degenerated protoplasm were found. Mesophyll cell plasmolysis and multi-vesicles between cell wall and plasma membrane and in cytoplasm were noticed. Number of mitochondria increased and reduction in thylakoids and intensive stained bodies in stroma (Plastoglubules) were found. Penoxsulam known as acetolactate synthase (ALS) inhibitor is involved in biosynthesis of the branched chain amino acids. It was found that the application of bispyribacsodium against E.colonum should reduce biosynthesis of amino acids which subsequently inhibits protein synthesis, growth, and finally causes cell and programmed cell death (WSSA, 2007). The formation of protein which is vital for membrane building and cell enlargement and division, may be disrupted and growth retardation may be induced as a result of cell enlargement and division inhibition. It is of interest to indicate that, re-growth of $E$. crus-galli and E. colonum treated with fenoxaprop-P-ethyl at rate of $26.25 \mathrm{gai} / \mathrm{fed}$ was noticed.

Cytological organelles seemed to be normal except irregular nuclei which were detected in E. colonum (Fig. 4). However, repetitive long-term use of herbicides with the same mode of action, combined with the global changes in modern agricultural assets (e.g. intensive cropping systems, monoculture, short rotations etc.), has imposed selection for resistance in previously susceptible weed species and populations (De Prado et al., 1997). The application of herbicides to large weed communities characterized by a high rate of genetic diversity exerts a strong selection pressure that may promote the evolution of resistance (Powles and Shaner, 2001). One gene encodes a plastidic ACCase, which is located in the chloroplasts, and the other gene encodes a cytosolic ACCase, which is located in the cytosol. The plastidic ACCase isoform is highly sensitive to ACCase-inhibitors and is therefore the target site for this herbicide group, while the cytosolic isoform is tolerant to these herbicides (Price et al., 2003; Delye \& Michel, 2005). Since ACCase-inhibitors are known to interfere with the activity of the carboxyl 
transferase domain (Sasaki and Nagano, 2004), mutations occurring within this region of the ACCase gene are likely to endow resistance to these herbicides (Balgheim, 2009 and Massa, 2011).
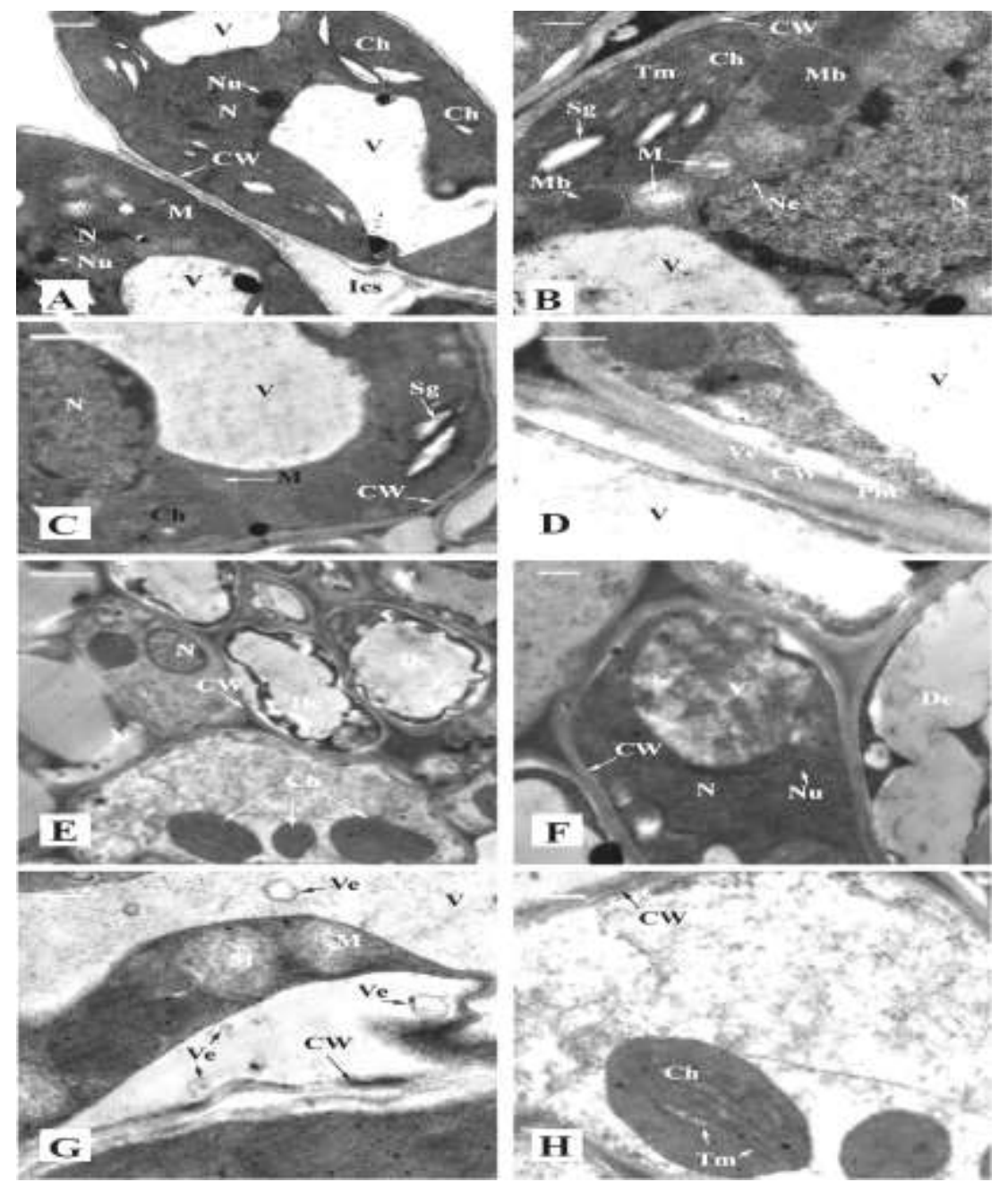

Fig. (3); Transmission electron micrograph of mesophyll cells of Echinochloa colonum. A and B: E. colonum (control), C and $D$ : $E$. colonum with fenoxaprop-ethyl at rate of 26.25gai/fed, E-H: E. colonum with penoxsulam at rate of 10 g a.i/fed. CW: cell wall, Ch: chloroplast, $M$ : mitochondria, $\mathbf{N}$ : nucleus, Nu: nucleolus, Nv: nuclear envelope, V: vacuole, Pm: plasma membrane, Tm: thylakoid membrane, Sg: Starch grain, Ve: vesicles, $\mathrm{Mb}$ : microbodies, Er: endoplasmic reticulum, Ics: inter cellular spaces (Bars: $A, B, E$ and $F=2$ $\mu \mathrm{m}, \mathrm{C}, \mathrm{D}, \mathrm{G}$ and $\mathrm{H}=\mathbf{5 0 0} \mathrm{nm}$ ). 
Acetyl-CoA carboxylase (ACCase, EC 6.4.1.2) is a key enzyme involved in the biosynthesis of fatty acids.
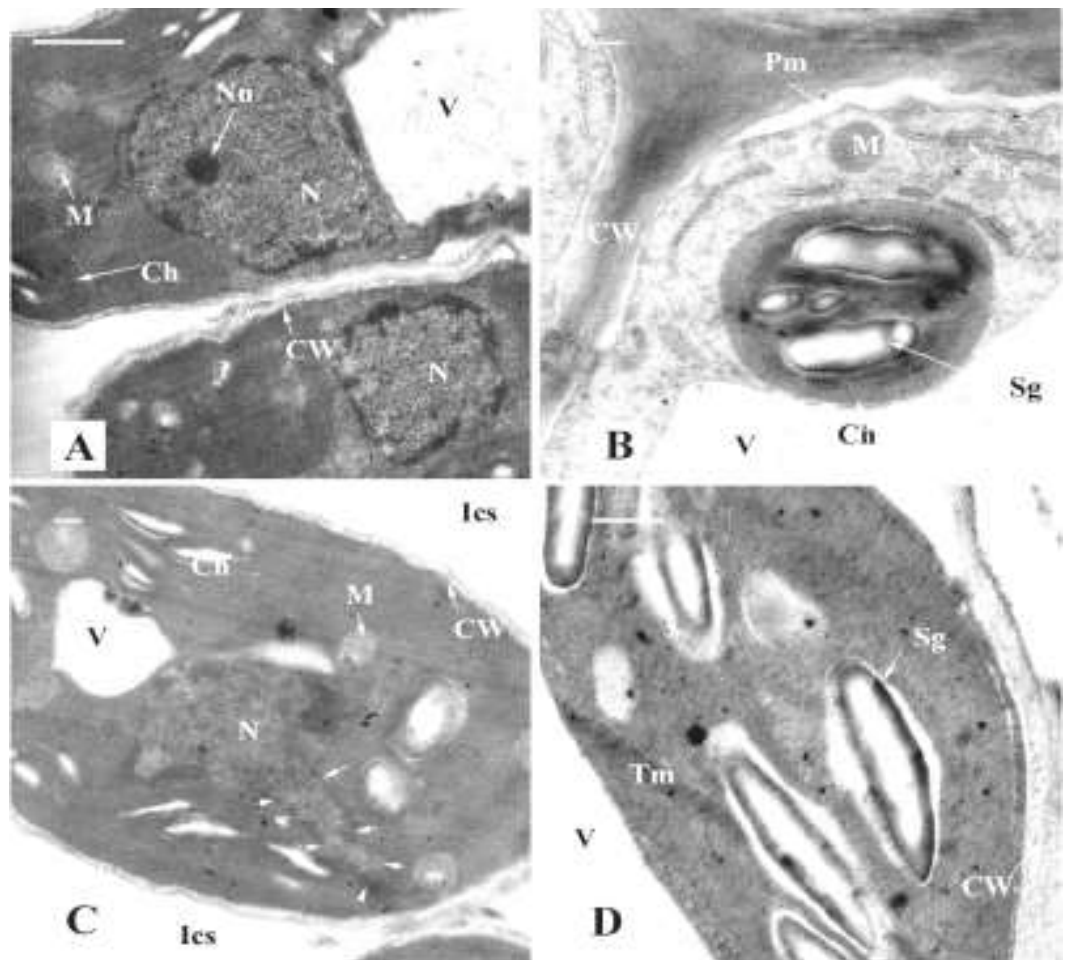

Fig. (4); Transmission electron micrograph of mesophyll cells of regrowth $E$. crus-galli and $E$. colonum treated with fenoxapropP-ethyl at rate of $26.25 \mathrm{~g}$ a.i /fed. A and B Echinochloa crusgalli with fenoxaprop-P-ethyl at the same rate, $C$ and $D$ : Echinochloa colonum with fenoxaprop-P-ethyl at rate of 26.25 g a.i /fed., CW: cell wall, Ch: chloroplast, M: mitochondria, N: nucleus, Nu: nucleolus, Nv: nuclear envelope, V: vacuole, Pm: plasma membrane, Tm: thylakoid membrane, Sg: Starch grain, Ve: vesicles, Mb: microbodies, Er: endoplasmic reticulum, Ics: inter cellular spaces (Bars: $A$ and $C=2 \mu \mathrm{m}, B-D=500 \mathrm{~nm}$ ).

This enzyme acts by catalyzing the formation of malonyl-CoA from the ATP-dependent carboxylation of acetyl-CoA (Powles \& Yu, 2010). ACCase-inhibiting herbicides suppress the activity of the ACCase enzyme, therefore inhibiting the regular biosynthesis of fatty acids; this presumably blocks the production of phospholipids used in building new membranes required for cell growth (HRAC, 2011). Under Egyptian conditions, there were significant differences between susceptible and resistant biotypes of $E$. crusgalli treated with fenoxaprop-P-ethyl with respect to chlorophyll content and growth reduction These differences concluded the ability to identify the 
occurrence of $E$. colonum resistant to bispyribac-sodium and assumed that the resistance mechanism was explained either by target site insensitivity or by an enhanced rate of metabolism. Furthermore, leaf protein analysis showed significant differences between the susceptible and resistant biotypes of $E$. colonum in the number and the density of protein bands (Zein, et al., 2010).

\section{Conclusion}

The obtained results are strong evidence that, cytological changes in wanted and unwanted plants were indicated. These findings beside target enzymes inhibitors will improve our understanding for the tested herbicides mode of action at the cell ultra structure characters.

\section{REFERENCES}

Abdeldayem, S. M. (2012). Biological and cytological studies on the effect of some herbicides as compared with the effect of rice Seedlings extracts on some rice weed. Ph.D.thesis, Faculty of Agriculture, Kafr-El Sheikh University, Kafrelsheikh, Egypt.

Anderson, W. P. (1996). Weed Sciences: principles and Application. 3d edn. West Publishing. Minneapolis. USA.

Anonymous.2003. Penoxsulam broad spectrum herbicide for rice. Global Technical Bull.Dow Agro-Science.Publication L45-137-002.

Balgheim N (2009) Investigations on herbicide resistant grass weeds. PhD dissertation, De-partment of Weed Science, University of Hohenheim, Stuttgart.

Baltazar, A. M. and De Datta, S. K. (1992). Weed management in rice. Weed Abstracts, 41 (11), pp. 495- 497. (C.F. Computer research).

Bao-Rang, Lu. (2004).Gene flow form cultivated rice: Ecological Consequences. ISB. News Report, May. Fundan University. Shanghai, pp. 1-3. (C.F. Computer research).

De Prado R., N. Martinez and R. Gimenez Espinosa (1997) Herbicideresistant Weeds in Europe: Agricultural, Physiological and Biochemical Aspects. In: Weed and Crop Resistance to Her-bicides (De Prado R, Jorrin J \& Garcia-Torres L eds.), 17-29. Kluwer Academic Publisher.

Delye C and S. Michel (2005) „Universal" primers for PCR-sequencing of grass chloroplastic acetyl-CoA carboxylase domains involved in resistance to herbicides. Weed Research 45, 323-330.

Donato Pastore, D., D. Trono, M. N. Laus, N. Di Fonzo and Z. Flagella (2007). Possible plant mitochondria involvement in cell adaptation to drought stress. A case study: durum wheat mitochondria. Journal of Experimental Botany, Vol. 58, No. 2, pp. 195-210.

Dutilleul C, Garmier M, Noctor G, Mathieu C, Che'trit P, Foyer CH, de Paepe R. 2003. Leaf mitochondria modulate whole cell redox homeostasis, set antioxidant capacity, and determine stress resistance through altered signaling and diurnal regulation. The Plant Cell 15, 1212-1226. 
Fischer A., Ramirez H.V., Lozano J. 1997. Suppression of junglerice [Echinochloa colona (L.) Link] by irrigated rice cultivars in Latin America. Agron. J. 521 (3): 516-521.

Gronwald, J. W. 1991. Lipid biosynthesis inhibitors. Weed Sci. 39:435

Gronwald, J.W.(1991) Lipid biosynthesis inhibitors, Weed Sci. 37: 435-449.

Hamza, A. M. (2009) Evoloution and resistance mechanism of some rice weeds against some herbicides, Ph.D. thesis, Faculty of Agriculture, Kafr-El Sheikh University, Kafrelsheikh, Egypt.

Hassan, S. M; Shebl, S. M and Abou El-Darag .(2002). Weed management in Rice. Annual Repot for 2001. In proceedings of the 6th National Rice Research and Development program workshop. Rice Research and training Center, Sakha, Kafr El-Shaikh. Egypt.

Heap, I. M. (1997). The occurrence of Herbicide-Resistant Weeds Worldwide. Pesticide Science 51, 235-243.

Hosaka, H. Inaba, H. Satoh, A. and Ishikawa, H. (1984). Morphological and histological effects of sethoxydim on corn (Zea mays) seedlings. Weed Sci. 32: 711-721.

HRAC (2011) Herbicide Resistance Action Committee. Available at: http://www.hracglobal.com.

IRRI (International Rice Research Institute), (1989). Toward 2000 and beyond. International Rice Research Institute. P.O.Box 933, 1099 Manila, Philippine, 66pp.

Jones, A. (2000). Does the plant mitochondrion integrate cellular stress and regulate programmed cell death? Trends in Plant Science 5, 225-230.

Kropff, M. J. (1993). Eco-physiological models for crop-weed competition. In Modeling crop-weed interaction, eds M.J.kropff and van Laar H. HX: X, pp. 25- 32 (C.F. Computer Research).

Kuk, Y. Wu, J. Derr, J. F. and Hatzios, K. K. (1999). Mechanism of Fenoxaprop Resistance in an Accession of Smooth Crabgrass (Digitaria ischaemum). Pest Biochem and Physiol., 64, 112-123.

Larelle, D. Man, R. Cavamna, S. Bemes, R. Duriatti, A. and Mavrotas. C. (2003). Penoxsulam, a new broad spectrum rice herbicide for weed control in European Union padies. In: Congress Proceedings of the BCPC International Congress -Crop Science and Technology. Glasgow, Scotland, November 10-12, 2003. British Crop Protection Council, Bracknell, Berks, UK. 1, p. 75-80.

Massa, D. (2011) Investigations on herbicide resistance in Apera spica-venti populations. Ph.D. dissertation, Institute of Phytomedicine, Department of Weed Science, Uni. Of Hohenheim, Germany.

Millar H, Considine MJ, Day DA, Whelan J. 2001. Unraveling the role of mitochondria during oxidative stress in plants. IUBMB Life 51, 201205.

Moss SR \& Cussans GW (1991) The development of herbicide-resistant populations of Alo-pecurus myosuroides (Black-Grass) in England. In: Herbicide Resistance in Weeds and Crops (Caseley JC, Cussans GW \& Atkin RK eds.), 45-56. Butterworth-Heinemann, Oxford. 
Naples M.L., Kessler P.J.A. 2005. Weeds of Rain Fed Lowland Rice Fields of Laos and Cambodia. MSc thesis, University of Leiden, Cambodia, 55 pp.

Osuna,M.D., Vidotto,F., Fischer,A.J.,Bayer,D.E.,De Pardo,R. and Ferrero,A. (2002). Cross-resistance to Bispyribac-sodium and bensulfuron-methyl in Echinochloa phyllopogon and Cypereus difformis.Pesticides Biochemistry \& Physiology, 73(1):9-17

Powles SB and Q. Yu (2010). Evolution in action: plants resistant to herbicides Annual Review of Plant Biology 2010;61:317-347.

Powles, S. B. and D. L. Shaner (2001) Herbicide resistance in world grains. CRC Press, Boca Ra-ton, Florida, USA.

Powles, S.B. and D. L. Shaner (2001) Herbicide resistance in world grains. CRC Press, Boca Ra-ton, Florida, USA.

Price L. J., D. Herbert, D. J. Cole and J. L. Harwood (2003) Use of plant cell cultures to study grami-nicide effects on lipid metabolism. Phytochemistry 63, 533-541.

Rhoads DM, Umbach AL, Subbaiah CC, Siedow JN. 2006. Mitochondrial reactive oxygen species: contribution to oxidative stress and interorganellar signaling. Plant Physiology 141, 357-366.

Rosskopf E.N, R. Charudattan and J. B. Kadir (1999) Use of plant pathogens in weed control. In: Handbook of Biological Control (Bellows TS \& Fisher TW eds.), 891-918.

Sasaki, Y. and Y. Nagano (2004) Plant acetyl-CoA carboxylase: structure, biosynthesis, regulation, and gene manipulation for plant breeding. 68(6):1175-84.

Spurr, A.R. (1969). Alow-vescosity resin embedding medium for electron microscopy. J. Ultrastruct. Res. 26: 31-43.

Tal, A., Romano, M. L. Stephenson, G. R. Schwan, A. L. and Hall J.C. (1993). Glutathione conjuction: a detoxification pathway for fenoxapropp-ethyl in barley, crabgrass, oat and wheat. Pest. Biochem. and Physiol. 46: 190-199.

Thelen, E. et al. (2001) The dynamics of embodiment: a field theory of infant perseverative reaching. Behav. Brain Sci. 24, 1-86

Valverde, B.E. and Itoh, K. (2001). World rice and herbicide resistance. In: Powles SB, Shaner DL, editors. Herbicide resistance and world grains. Boca Raton, Florida (USA): CRC Press LLC. 195-249.

Venable, J. H. and R. Coggeshall (1965). A simplified lead citrate stain for use in electron microscopy. J. Cell Biol. 25, 407.

Wisler, G. C. and R. Norris R (2005) Interactions between weeds and cultivated plants as related to management of plant pathogens. Weed Science 53, 914-917.

Wright, J. P. (1994). Use of membrane potential measurements to study mode of action of diclofop-methyl. Weed Sci. 42: 285-292.

WSSA (Weed Science Society of America). (2007). Herbicide Handbook (W.K. Vencill, ed.). 9th ed. Lawrence, KS. 493 pp.

WSSA, (1994) Fenoxaprop, in: WSSA Herbicide Handbook, seventh ed. Weed Science Society of America, Champaign, IL, pp. 126-128. 
Zein, A. A., ABD-EL-Baky M. A., Hassan, S M., Derbalah1, A. S. and Hamza, A. M. (2010). Evolution and Mechanism of Rice Weeds Resistance to Herbicidesl-Resistanceof Echinochloa colonum to Bispyribac-sodium Herbicide with respect to its Effect on Chlorophyll Content. J. Agric. Res. Kafer El-Sheikh Univ., 36(4):480-495.

دراسة التغيرات الخلوية الاقيقة في نباتـات الأرز وحشيثتي الانيبة وأبو ركبة تم

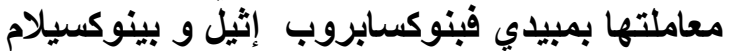

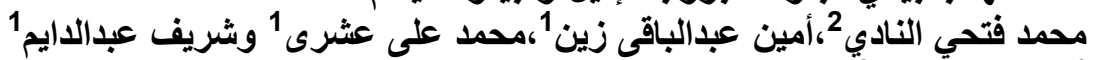

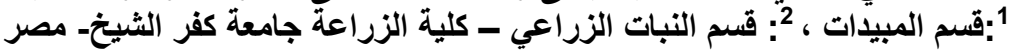

هدفت هذه الدراسة للتعرف على التغير ات السيتولوجية في نباتات الأرز وحشيشتي الدنيبة

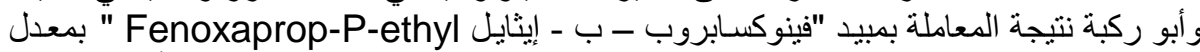

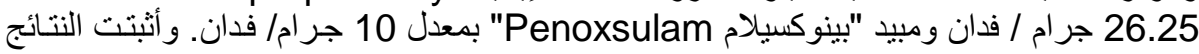

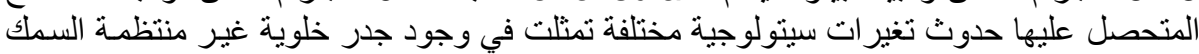

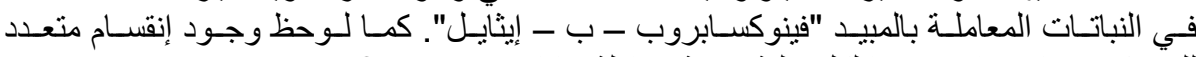

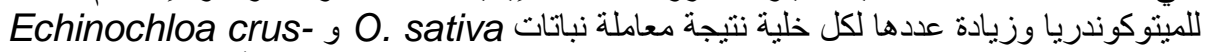
galli

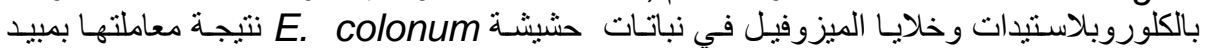

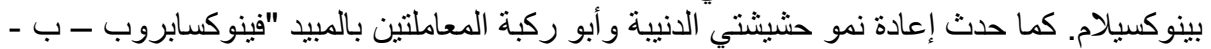

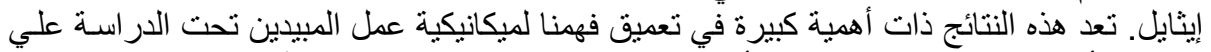
نباتات الأرز وكذلك حشيشتي الدنية وأبو ركبة والتي قد تساعد في تجنب الآثار السيئة التي تحدث

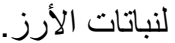

كلية الزراعة - جامعة المنصورة كلية الزراعة - جامعة الاسكندرية

$$
\begin{aligned}
& \text { قام بتحكيم البحث } \\
& \text { أ.د / سلوى السعيد نجم البحث } \\
& \text { أ.د / على تاج الدين }
\end{aligned}
$$

